\title{
CARE REPORT
}

\section{Application of Platelet-Rich Fibrin and Injectable Platelet-Rich Fibrin in Combination of Bone Substitute Material for Alveolar Ridge Augmentation - a Case Report}

\author{
Ivan L. Chenchev, Vasilena V. Ivanova, Deyan Z. Neychev, Radka B. Cholakova \\ Department of Oral Surgery, Faculty of Dental Medicine, Medical University of Plovdiv, Plovdiv, Bulgaria
}

\section{Correspondence: \\ Ivan L. Chenchev, Department of Oral Surgery, Faculty of Dental Medicine, Medical University of Plovdiv, Bulgaria, 3 Hristo Botev Blvd., 4002 Plovdiv, Bulgaria E-mail: ivan.chenchev@gmail. com \\ Tel: +359 888722321}

Received: 01 Mar 2017

Accepted: 22 Mar 2017

Published Online: 26 Apr 2017

Published: 29 Sep 2017

Key words: injectable plateletrich fibrin, platelet-rich fibrin, bone substitute material, alveolar ridge augmentation, regeneration

Citation: Chenchev IL, Ivanova VV, Neychev DZ, Cholakova RB. Application of platelet-rich fibrin and injectable plateletrich fibrin in combination of bone substitute material for alveolar ridge augmentation case report.

Folia Medica 2017;59(3):362-366 doi: 10.1515/folmed-2017-0044
Background: Different barrier membranes and augmentation techniques are used in oral surgery to recover lost bone structures with varied success. Recently, a combination between bone graft materials and Platelet-Rich-Fibrin (PRF) is implemented in the periodontology and implantology.

Aim: The aim of this case report was to assess the possibility for augmentation of the alveolar ridge in the frontal region of the upper jaw, utilizing a combination of bone graft material, injectable platelet-rich-fibrin (i-PRF) and advanced platelet-rich fibrin (A-PRF).

Materials and methods: An 18 year-old male with expulsion of tooth 11 and partial fracture of the alveolar ridge was treated with augmentation of the alveolar ridge using bone graft material, injectable platelet-rich-fibrin(i-PRF) and advanced platelet-rich-fibrin (A-PRF). Clinical results were reviewed 4 months after the augmentation and a dental implant was placed.

Results: The postoperative period was uneventful. The control CBCT scan showed good organization of new bone allowing placement of a dental implant.

Conclusion: The successful clinical and radiographic results of the case suggest that using A-PRF and i-PRF can be beneficial for bone augmentation of the alveolar ridge before implant placement.

\section{BACKGROUND}

There are many reasons for local or generalized atrophy of the jaws, but the loss of teeth is considered paramount. ${ }^{1}$ After losing compromised teeth, bone resorption is most pronounced during the first year and is at its peak during the first 3 months. ${ }^{2}$ Bone resorption is progressive and cumulative and it continues throughout the whole life. ${ }^{3}$ The progressive atrophy which occurs after tooth loss is often associated with difficulties in conventional prosthetic treatment, thus a reason for esthetic and functional complications. Different barrier membranes and augmentation techniques are used in oral surgery to recover lost bone structures with varied success.
The majority of authors recognize the autogenous bone as the "golden standard". The autogenous bone is the only one that has osteogenic, osteoinductive and osteoconductive qualities, while other materials possess only osteoconductive properties. ${ }^{4}$ It is well known that PRF is able to stimulate integration and remodulation of bone structure. Using the PRF membrane in bone regenerative surgery accelerates the healing of soft tissues and protects the gingiva from dehiscences. ${ }^{5,6}$ According to Del Corso, the strategy to combine PRF membrane with adequate bone graft material is a form of in vivo tissue engeneering called - Natural Bone Regeneration (NBR). ${ }^{7}$ PRF incorporates many growth factors 
and other bioactive compounds, that support revascularisation and regeneration of bone and soft tissues. The aim of this case report is to evaluate the possibilities for augmentation of the alveolar ridge with a combination of xenograft, i-PRF and A-PRF membrane.

\section{CASE REPORT}

An 18-year-old male was referred for treatment at the Department of Oral Surgery at FDM, MUPlovdiv. On clinical examination expulsion of tooth several holes were made on the cortical plate of the bone over the defect. The previously prepared APRF membrane was cut into pieces with scissors or scalpel and then mixed with the bone graft material and plasma, separated from the PRF (Fig. 3). The bone defect was filled with the mixture of bone-graft material and A-PRF membrane pieces. The bone-graft mixture was infiltrated with an ex-tempore prepared $i-P R F$ with the help of a syringe and needle (Fig. 4). The A-PRF membrane was placed to cover the $i$-PRF infiltrated bone graft and then sutured to

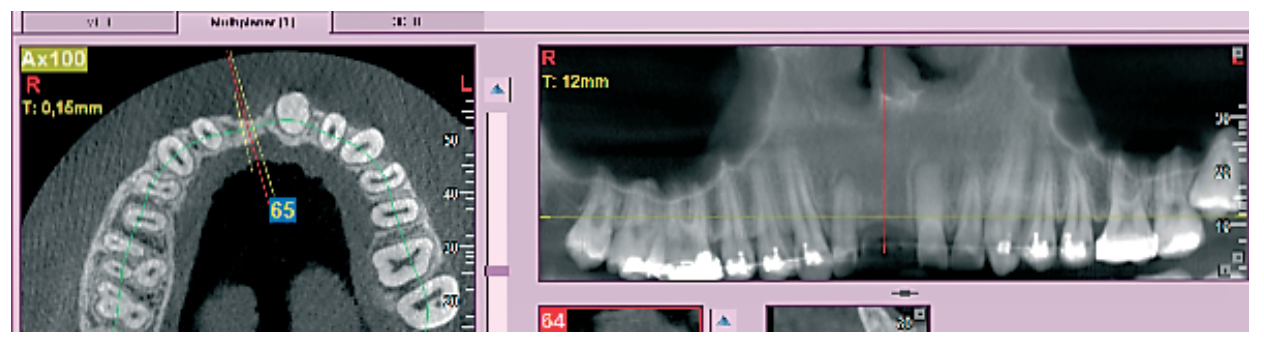

Figure 1. 3D CBCT scan before surgery.

11 and partial fracture of the alveolar ridge were observed. CBCT scan was performed before the operation, to evaluate bone loss on the labial side (Fig. 1). A treatment plan which involved alveolar ridge augmentation with xenograft combined with $A-P R F$ and $i-P R F$ with following dental implantation was suggested.

\section{Preparation of the A-PRF Membrane AND THE I-PRF}

After the venipuncture of $v$. cubity with a $10 \mathrm{ml}$ vacuum test-tube (Advanced-PRF ${ }^{\mathrm{TM}}$ ), $9 \mathrm{ml}$ of blood was taken from the patient. The blood was then immediately put into a PRF DUO (Process for PRF®-France) centrifuge for 8 minutes at 1300 rpm. The A-PRF membrane, in our methodology, 8 was formed out of two A-PRF clots by putting them on top of one another - the areas bordering with the red part were put at the opposite ends and it was then dried in a metal box - A-PRF Box $\AA$. To obtain the $i-P R F$, venous blood was drawn from the patients in special tubes. The manipulation was performed immediately before using the i-PRF. The tubes were then placed in a centrifugal machine at a 700 rpm for 3 minutes.

\section{SURGiCAL TREATMENT}

After performing adequate local anesthesia trapezoidal full-thickness flap was raised. The flap was reflected with a periosteal elevator above the margins of the defect (Fig. 2). With a small round bur or an appropriate tip of a piezosurgery unit, the adjacent soft tissues using self-resorbing suture material. The full-thickness mucoperiosteal flap should cover the wound without tension. Therefore a horizontal scoring of the periosteum parallel to the primary incision was done. The flap was adapted and tightly sutured over the PRF membrane without tension (Fig. 5). The patient was kept under antibiotic coverage for 5 days (ampicillin 3x $1 \mathrm{~g}$ ) along with analgesics for 3 days. A follow-up CBCT scan was made four months after the augmentation. It revealed successful augmentation of the alveolar ridge. The dental implant was placed in the area of tooth 11 (Fig. 6).

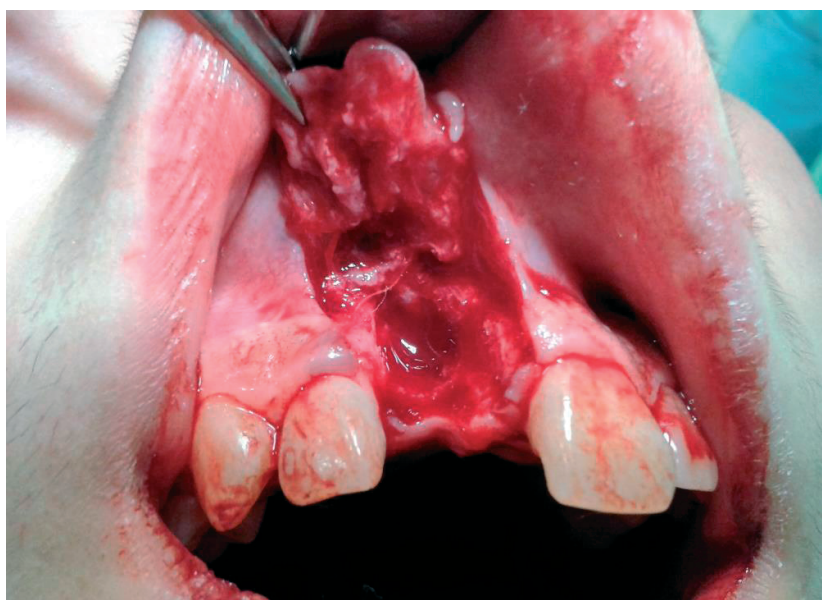

Figure 2. Reflected mucoperiosteal flap over the bone defect in the area of tooth 11 . 


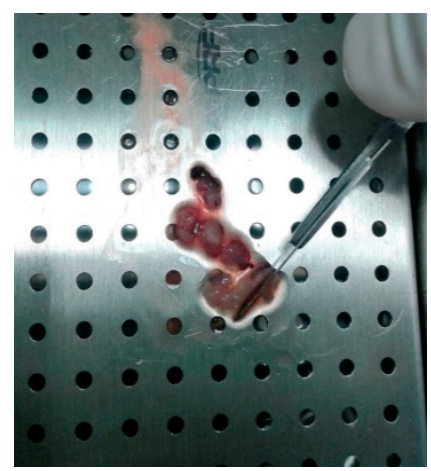

a

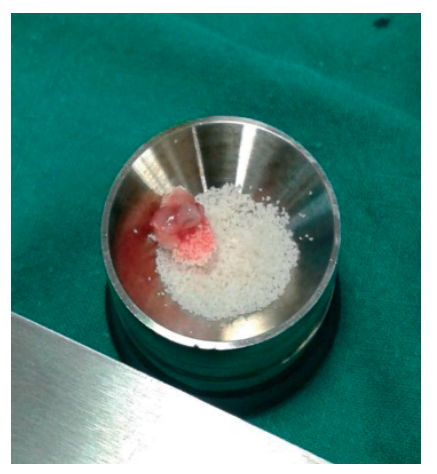

b

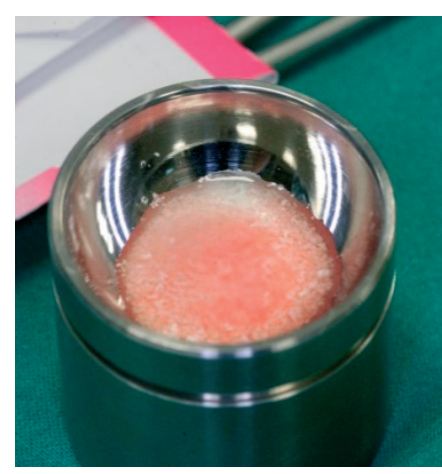

c

Figure 3. a) Cutting the PRF membrane into small pieces; b) Mixing the bone-graft material with the parts of the PRF membrane and c) The prepared mixture.

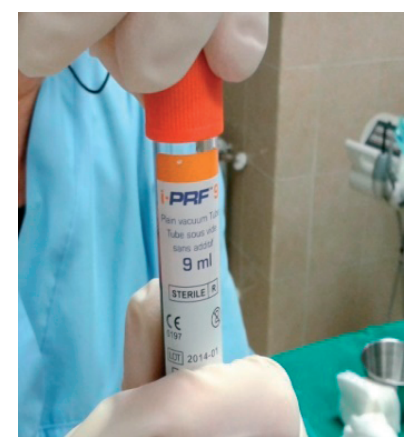

a

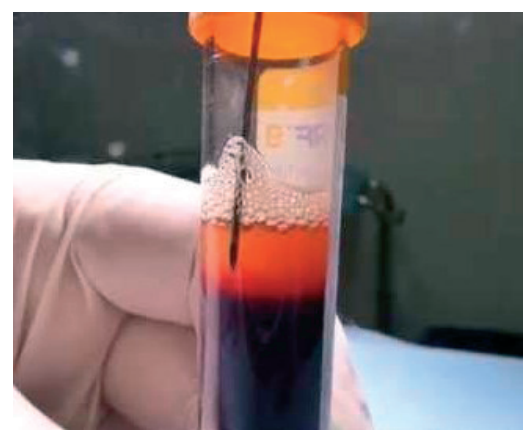

$\mathrm{b}$

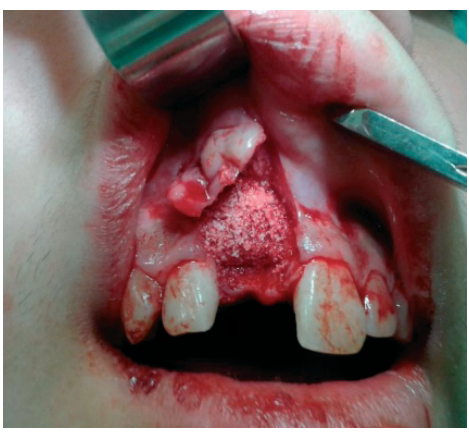

c

Figure 4. a) Test tube with the prepared i-PRF; b) Aspiration of i-PRF with a needle and syringe c) Mixture of i-PRF, A-PRF and bone graft material placed in the area of tooth 11.

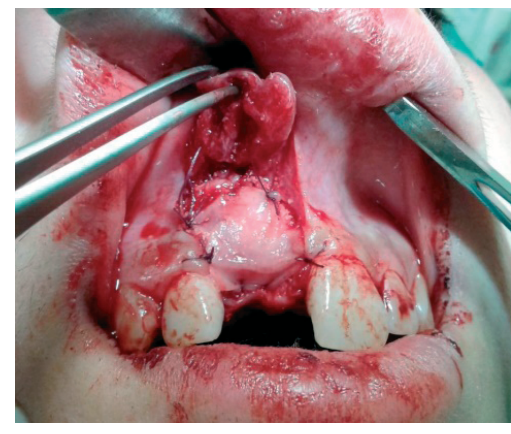

a

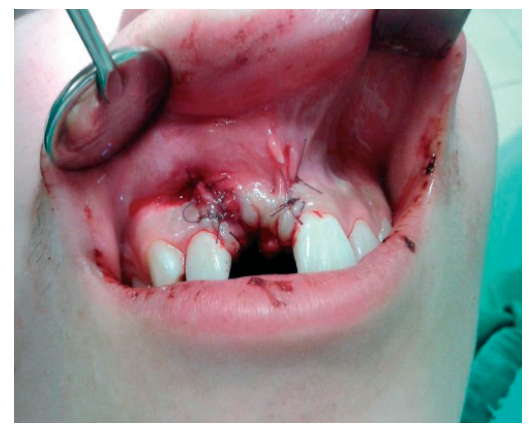

$\mathrm{b}$

Figure 5. a) Placed and sutured PRF membrane in the area of tooth 11 ; b) A flap sutured over the graft mixture and the A-PRF membrane covering it.

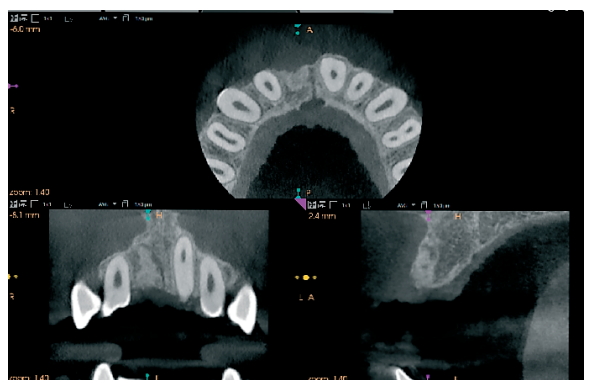

a

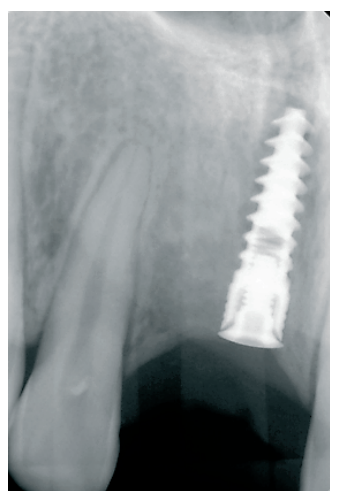

b

Figure 6. a) 4 months follow up CBCT; b) Intraoral radiograph after placing dental implant in the area of tooth 11. 


\section{DISCUSSION}

Placement of dental implants is directly related to the volume of the remaining alveolar bone. It is necessary to create new bone structure when there is an absence of a sufficient volume, in order to place a dental implant. To form new bone structure, the bone graft material must be biocompatible and able to withstand the biomechanical stress. ${ }^{9}$ Using bone grafts is very successful when it is performed in an environment with good blood supply. This depends on the primary wound closure and the condition of the adjacent bone. Good blood flow assures the necessary cells, growth factors and promoters for the osteogenic-biomineralisation cascade. ${ }^{9} \mathrm{~A}$ biological connector between the different parts of the bone graft material is obtained when it is mixed with A-PRF and i-PRF. PRF assists angiogenesis, engagement of the stem cells and migration of osteogeneous cells in the central part of the graft. ${ }^{11,12}$ According to Toffler $\mathrm{M}$ et al. ${ }^{10}$ using PRF membrane in augmentation procedures is beneficial for better wound closure and faster recovery of the soft tissues. Other authors concluded that the use of PRF reduces postoperative pain, swelling and minimizes the infection phenomenon. ${ }^{13}$ Yilmaz D et al. ${ }^{14}$ suggest that the use of PRF in combination with $\beta$-TCP could accelerate new bone formation and this combination is a very good alternative to the independent use of $\beta$-TCP. Ozdemir $\mathrm{H}$ et al. ${ }^{15}$ use PRF as a bone graft material in combination with rigid titanium membranes for regeneration of bone defects in the calvaria of rabbits. The results of the combination of PRF and titanium membrane showed the highest quantity and quality of new bone formation compared with xenografts (Bio-Oss) and $\beta$-TCP. The good clinical results in our case report show that the addition of PRF and i-PRF to bone graft materials improves their properties. Mixing of bone graft material with pieces of PRF and its infiltration with i-PRF leads to delivery of growth factors inside the wound, which helps the migration of osteopromotor cells and attracts circulating stem cells to the wound (fast angiogenesis). ${ }^{12}$ Adding PRF to the bone graft reduces the required bone graft material volume and improves its manipulative qualities. The use of PRF accelerates the healing of hard and soft tissues, and the use of PRF membrane instead of another barrier membrane reduces the cost of the procedure.

\section{CONCLUSION}

The good clinical results achieved in this case report support the data found in the literature that the use of PRF increases the amount of growth factors inside the wound and improves the qualities of the bone graft material. Further research and more clinical cases are needed to confirm the achieved results.

\section{REFERENCES}

1. Albrektsson T, Zarb GA, Worthington P, et al. The long-term efficacy of currently used dental implants: a review and proposed criteria of success. Int J Oral Maxillofac Impl 1986;1:1-25.

2. Ten Heggeler JM, Slot DE, Van der Weijden GA. Effect of socket preservation therapies following tooth extraction in non-molar regions in humans: a systematic review. Clin Oral Implants Res 2011;22:779-88.

3. Tallgren A. The continuing reduction of the residual alveolar ridge in complete denture wearers. A mixed longitudinal study covering 25 years. J Prosthet Dent 1972;27:120-32.

4. Van der Wal KGH, de Visscher J, Stoelinga JW. The autogenous inner table iliac bone graft. Int J Oral Maxillofac Surg 1986;14:22-5.

5. Del Corso M, Mazor Z, Rutkowski JL, et al. The use of leukocyte- and platelet-rich fibrin during immediate postextractive implantation and loading for the esthetic replacement of a fractured maxillary central incisor. J Oral Implantol 2012;38(2):181-7.

6. Gassling V, Douglas T, Warnke PH, et al. Plateletrich fibrin membranes as scaffolds for periosteal tissue engineering. Clin Oral Implants Res 2010;21(5):543-9.

7. Del Corso M, Dohan Ehrenfest DM. Immediate implantation and peri-implant natural bone regeneration (NBR) in the severely resorbed posterior mandible using leukocyte- and platelet-rich fibrin (L-PRF): a 4-year follow-up. POSEIDO 2013;1(2):109-16.

8. Chenchev I, Neichev D, Vicheva D, et al. Vista technique and platelet-rich fibrin membrane for treatment of multiple adjacent gingival recessions - 6 month follow-up. IOSR Journal of Dental and Medical Sciences 2016;15(7):128-33.

9. Wang HL, Boyapati L. "PASS" principles for predictable bone regeneration. Implant Dent 2006;15(1):8-17.

10. Toffler M, Toscano N, Holtzclaw D, et al. Introducing Choukroun's platelet rich fibrin (PRF) to the reconstructive surgery milieu. The Journal Implant Adv Clin Dent 2009;1:21-30.

11. Ghanaati S, Booms P, Orlowska A, et al. Advanced platelet-rich fibrin: a new concept for cell-based tissue engineering by means of inflammatory cells. J Oral Implantol 2014;40(6):679-89.

12. Mourao C, Valiense H, Melo R, et al. Obtention of injectable platelets rich-fibrin (i-PRF) and its po- 
lymerization with bone graft: technical note. Rev

Col Bras Cir 2015;42(6):421-3.

13. Pacifici A, Carbone D, Soda G, et al. Guided bone regeneration procedure with platelet-rich fibrin (PRF) membranes in resolution of a severe maxillary bone defect: report of case. Senses Sci 2015;2(1):64-70. 14. Yilmaz D, Dogan N, Ozkan A, et al. Effect of platelet rich fibrin and beta tricalcium phosphate on bone healing. A histological study in pigs. Acta Cir Bras 2014;29:59-65.

15. Ozdemir H, Ezirganil S, Kara MI, et al. Effect of Platelet-rich Fibrin alone used with rigid titanium barrier. Arch Oral Biol 2013;58(5):537-44.

\title{
Применение фибрина, обогащённого тромбоцитами и инъекционного фибрина, обогащённого тромбоцитами в комбинации с материалом для замены костей для наращивания альвеолярного отростка - клинический случай
}

\author{
Иван Л.Ченчев, Василена В. Иванова, Деян 3. Нейчев, Радка Б. Чолакова \\ Кафедра оральной хирургии, Факультет дентальной медицины, Медицинский университет - Пловдив, Пловдив, Болгария
}

\begin{abstract}
Адрес для корреспонденции: Иван Л. Ченчев, Кафедра оральной хирургии, Факультет дентальной медицины,

Медицинский университет -

Пловдив, бул. „,Христо Ботев“" № 3, Пловдив, Болгария

E-mail: ivan.chenchev@gmail.com Тел: +359 888722321
\end{abstract}

Дата получения: 01 марта 2017 Дата приемки: 22 марта 2017 Дата онлайн публикации: 26 апреля 2017

Дата публикации: 29 сентября 2017

\section{Ключевые слова: \\ инъекционный \\ фибрин,обогащённый \\ тромбоцитами, \\ фибрин,обогащённый \\ тромбоцитами, материал \\ для замены костей, \\ наращивание альвеолярного \\ отростка,регенерация}

Образец цитирования:

Chenchev IL, Ivanova VV, Neychev DZ, Cholakova RB. Application of platelet-rich fibrin and injectable platelet-rich fibrin in combination of bone substitute material for alveolar ridge augmentation - case report.

Folia Medica 2017;59(3):362-366. doi: 10.1515/folmed-2017-0044
Введение: Для реконструкции потерянных костных структур в оральной хирургии применяются с переменным успехом различные барьерные мембраны и методы наращивания. В последнее время в парадонтологии и имплантологии применяется комбинация из материалов для костной трансплантации и фибрина, обогащённого тромбоцитами (ФОТ).

Цель: Целью настоящего клинического случая является оценка возможности наращивания альвеолярного отростка лобного отростка верхней челюсти с применением комбинации из материала для костной трансплантации, инъекционного фибрина, обогащённого тромбоцитами (injectable platelet-richfibrin (i-PRF)) и улучшеного фибрина, обогащённого тромбоцитами (advanced platelet-rich-fibrin (A-PRF)).

Методы: Мужчина восемнадцатилетнего возраста с удалённым одиннадцатым зубом и частичной фрактурой альвеолярного отростка прошёл курс лечения, включающий наращивание альвеолярного отростка с применением материала для костной трансплантации, инъекционного фибрина, обогащённого тромбоцитами (i-PRF) и улучшенного фибрина, обогащённого тромбоцитами (A-PRF). Клинические результаты были рассмотрены по истечении 4 месяцев после наращивания и установки зубного импланта.

Результаты: Послеоперационный период прошёл гладко и контрольное СВСТ сканирование показало хорошее формирование новой кости, позволяющее установку зубного импланта.

Заключения: Успешные клинические и рентгенографические результаты случая показывают, что применение A-PRF и і-PRF может быть полезным для костного наращивания альвеолярного отростка перед установкой импланта. 